\title{
INNOVATIVE APPROACHES IN THE DIAGNOSIS OF THE PUPIL'S LEARNING STYLE
}

\author{
Zdeňka KRIŠOV $\boldsymbol{A}^{*}$, Základní škola Ruda nad Moravou, Česká republika \\ Jan LAVRINČÍK, Moravská vysoká škola Olomouc, Česká republika
}

Přijato: 12. 6. 2019 / Akceptováno: 23. 8. 2019

Typ článku: Výzkumný článek

DOI: $10.5507 /$ jtie.2019.008

Abstract: The article deals with learning styles. It is dedicated to their diagnostics with the support of information and communication technologies. Determining the learning style of pupils is an important piece of information for both the teacher and the pupil. It will enable the teacher to explore new ways of approaching the learner, to use new methods and innovative learning practices. The paper describes a fuzzy language model that allows the learning style of a pupil and its implementation in LFLC. The aim of the paper is to show how different styles of learning can be identified using artificial intelligence methods to help them make their learning process more effective.

Key words: learning styles, innovation in teaching, expert systems, language fuzzy model.

\section{INOVATIVNÍ PŘÍSTUPY PŘI DIAGNOSTICE UČEBNÍHO STYLU ŽÁKA}

Abstrakt: Článek se zabývá styly učení. Je věnován jejich diagnostice s podporou informačnich a komunikačnich technologii. Určeni učebního stylu žákủ je důležitou informací pro pedagoga i žáka. Vyučujicímu umožni hledat nové cesty prístupu $k$ žákovi, využivat nové metody a inovativni postupy učení. Př́spěvek popisuje jazykový fuzzy model, který umožňuje určení učebního stylu žáka, a jeho implementaci v prostředí LFLC. Cílem príspěvku je ukázat, jak lze $s$ využitím metod umělé inteligence rozpoznat různé styly učení žáků a napomoci jim tak $k$ zefektivněni vlastního procesu učení.

Klíčová slova: styly učení, inovace ve výuce, expertní systémy, jazykový fuzzy model.

*Autor pro korespondenci: krisova@seznam.cz 


\section{1 Úvod}

Učení je pojem, se kterým se setkáváme od nepaměti. Je součástí našeho života, Jedná se o celoživotní, aktivní a tvořivý proces, který rozšiřuje vrozené dispozice a možnosti jedince. Má svůj význam v získávání, osvojování, pozměňování a upevňování nových zkušeností. Během učení každý člověk zpracovává spoustu informací a přistupuje k nim různým zpo̊sobem. Specifický osobní styl, kterým každý jedinec zaznamenává a zpracovává informace, se nazývá styl učení. Styl učení se vyvíjí z vrozeného základu, ale během života se proměňuje záměrně i bezděčně. Dává žákovi částečnou odpověd' na otázku „Jak se učit?“, nebot' stojí v pozadí toho, co žák skutečně dělá, i toho, o co při učení usiluje, i když se mu to třeba úplně nedaří. Nicméně kvalitu a efektivitu učení žáka tak silně ovlivňuje.

Významně by měla kvalita a různost stylů učení ovlivňovat i kvalitu rrízení učení, povahu a intenzitu pomoci učitele v učení žáků. Vždyt' řízení učení ve vyučování znamená, mimo jiné i záměrné vstupování do učebního stylu žáka - a to ve smyslu jeho využívání i ve významu jeho kultivace, zkvalitňování a změny prospěšné pro žáka a jeho učební činnosti.

\section{Styly učení}

Jednoznačně vymezit styl učení však není snadné. V odborné literatuře je možné najít velký počet definic, které jsou však nejednotné. Napřr. dle Kostolányové patří mezi často uváděné charakteristiky žáka, které mohou ovlivnit jeho učební styl:

- $\quad$ typické způsoby jednání, predispozice a preference, které jedinec využívá při učení a vyučování,

- $\quad$ proces zpracování informací,

- $\quad$ charakteristiky osobnosti (Kostolányová, 2012).

V rámci výzkumu stylů učení byly studovány tyto i jiné vlastnosti žáků, související s učením, vznikla řada teorií učebních stylů, dle kterých byli žáci diagnostikováni a řazeni do jednotlivých typů. Mezi nejvýznamnější publikace zabývající se problematikou učebních stylů patří díla autorů Coffield (2004), Dunn a Dunn (1979), Felder a Silverman (1998), Gregorec (1979), Honey a Mumford (2002), Pask (1976), Riding a Cheema (1991) a v České republice zejména autorů Mareš (1998), Kostolányová (2012) a Vlčková (2007).

Styl učení vede žáka obvykle k učebním výsledkům určitého typu, ale znesnadňuje dosažení jiných, často lepších, výsledků. Je to způsobeno i tím, že žák si zpravidla neuvědomuje svůj styl učení, systematicky jej neanalyzuje a promyšleně nezlepšuje. Vnímá styl učení jako postup samozřejmý, běžný, jemu vyhovující (Mareš, 1998).

Styly učení se však dají diagnostikovat a do jisté míry i měnit pomocí sociálního prostředí nebo jedincem samotným. Poznání učebního stylu je tedy užitečné pro žáka samotného, ale i pro pedagoga, který může individualizovaně zasáhnout do průběhu jeho učení. Styly učení lze diagnostikovat dle různých metod. My jsme k určení stylu učení žáka využili nástrojů umělé inteligence, konkrétně expertní systémy.

\section{Expertní systém}

Expertní systémy jsou počítačové programy, které simulují rozhodovací činnost expertů při řešení velmi složitých, úzce problémově zaměřených úloh. Hovoříme-li 
o řešení určitých úkolů, máme na mysli úkoly komplikované, složité. Složitost úkolu pak lze ohodnotit počtem všech variant jeho řešení, které připadají v úvahu. Expertní systémy dokáží takový úkol řešit inteligentním způsobem. Jedná se o takový postup, kdy jsou ověřovány pouze varianty nadějné. Ty, které neposkytují dostatečnou šanci na úspěch řešení, budou apriorně vynechány. Přitom mechanizmus, který umožňuje řešiteli některé varianty apriori odmítnout, je nesporně založen na využívání informací, znalostí o řešeném problému.

Ukazuje se, že využití znalostí je pro konstrukci inteligentních postupů zcela relevantní. Znalosti mohou být získány jednak převzetím od člověka, který je schopen úlohu inteligentně řešit (tedy nutně experta $\mathrm{v}$ daném oboru - $\mathrm{v}$ našem př́padě zkušeného učitele), jednak analýzou př́íkladů a jejich inteligentních řešení (Mikulecký, Hynek a Lenharčík, 2002). Expertní systémy jsou založeny na myšlence převzetí znalostí od experta (tj. jeho znalostí objektivních i subjektivních) a jejich vhodné počítačové reprezentace, která by umožnila počítačovému programu využivat těchto znalostí zhruba stejným způsobem, jako jich využívá expert (Popper a Kelemen, 1989).

\section{Struktura expertního systému}

Jádro takového systému (Obr. č. 1) tvoří ř́dicí (inferenční) mechanizmus, který operacemi nad bází znalostí na základě aktuálních dat (dotazu) upřesňuje (aktualizuje) obecný model a vyvozuje odpověd'- závěr (Pokorný, 1996).

Báze znalostí jako obecný model chování studované soustavy je tvořena expertními znalostmi, které jsou formalizovány vhodnou reprezentací. Kromě pravidlové reprezentace, která je preferována $v$ tomto příspěvku, existuje řada dalších možností.

Aktualizace modelu je provedena vstupem konkrétních dat $\mathrm{k}$ danému prípadu. Konkrétní data jsou reprezentována bází dat a mohou být získána jako jazykové hodnoty od uživatele (operátora), př́mým měřením nebo kombinovaně.

Výsledkem činnosti diagnostického expertního systému je seznam ohodnocených závěrů - cílových hypotéz (diagnóz).

Uživatelsky významnou částí expertního systému je vysvětlovací podsystém. Ten poskytuje informace o konkrétním postupu, jímž bylo dosaženo závěru. Tak může uživatel sám posoudit kvalitu báze znalostí i inference a výsledek odvození př́padně dodatečně modifikovat.

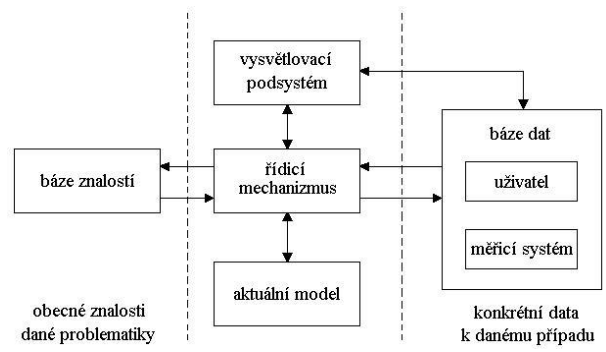

Obr. č. 1: Struktura diagnostického expertního systému (Pokorný a Krišová, 2016). 
Lze ř́ci, že cílem expertního systému je dosahovat obdobně kvalitních závěrů při řešení složitých problémů, jako by stejný problém řešil člověk-expert v daném oboru. Expertní systémy jsou schopny efektivně využívat eventuální nejistoty jak v bázi znalostí, tak v bázi dat.

\section{Fuzzy orientované expertní systémy}

Typickou vlastností expertních systémů je schopnost efektivně využít neurčitosti nekonvenčních modelů neurčitých (vágních) soustav. Základem těchto modelů je počítačová reprezentace expertních znalostí (mentálních modelů expertů). Jednotlivé typy expertních systémů se liší způsobem reprezentace znalostí a způsobem formalizace jejich přirozené neurčitosti.

V praxi velmi rozšířené jsou expertní systémy, které využívají reprezentace znalostí formou podmíněných pravidel a formalizace jejich neurčitostí pomocí aparátu fuzzy množinové matematiky. Jako inferenční (vyvozovací) mechanizmy využívají tyto modely př́stupy jazykové fuzzy logiky.

\section{Jazykový pravidlový fuzzy model}

Jazykový pravidlový fuzzy model typu Mamdani, který bude dale využit, je dán množinou $r=1,2, \ldots, \mathrm{R}$ pravidel typu $I F-T H E N$. Jeho $r$-té pravidlo má tvar (Novák, 2000)

IF $\left[x_{1}\right.$ is $A_{\mathrm{r}}\left(x_{1}\right)$ and $x_{2}$ is $A_{\mathrm{r}}\left(x_{2}\right)$ and $\ldots$ and $x_{\mathrm{n}}$ is $\left.A_{\mathrm{r}}\left(x_{\mathrm{n}}\right)\right]$ THEN $\left[y\right.$ is $\left.B_{\mathrm{r}}(y)\right]$

Levá strana pravidla se nazývá antecedent (předpoklad), pravá konsekvent (důsledek, závěr). Antecedent je složen $\mathrm{z}$ fuzzy konjunkce dílčích fuzzy tvrzení o velikosti vstupních proměnných, konsekvent obsahuje fuzzy tvrzení o odpovídající velikosti výstupní proměnné.

Pro interpretaci fuzzy logických spojek (fuzzy konjunkce, fuzzy disjunkce, fuzzy implikace) lze využít - na rozdíl od logiky konvenční - různé, variantní předpisy (funkce t-normy, funkce t-konormy, fuzzy implikační funkce), (Novák, 1990).

Pro vyvození velkosti výstupní proměnné při uvažování konkrétních hodnot proměnných vstupních byla použita Mamdaniho vyvozovací metoda. Ta předpokládá, že fuzzy konjunkce mezi tvrzeními vantecedentu je interpretována jako obyčejná konjunkce (min), fuzzy implikační funkce THEN je interpretována jako Mamdaniho implikace (min) a jednotlivá pravidla jsou spojena fuzzy disjunkcí interpretovanou jako obyčejná disjunkce (max). Vysvětlení této metody vyžaduje hlubší znalosti fuzzy operací, které lze získat např̀ v práci Pokorného (Pokorný, 2012).

\section{Jazykový model pro diagnostiku učebního stylu}

Při určování učebního stylu žáka byl vytvořen expertní systém ESl. Jeho jazykový fuzzy model sleduje následující charakteristiky žáka, které styl učení mohou ovlivňovat:

- $\quad$ sociální aspekt - charakterizuje, jaký způsob zapojení do okolního sociálního prostředí, žák při studiu preferuje,

- způsob zpracování informací - rozlišuje preferenci teorie nebo praktického experimentování, 
- $\quad$ smyslové vnímání - charakterizuje, kterým smyslem žák nejlépe vnímá, jakou formou informaci nejlépe pochopí a zapamatuje si ji,

- $\quad$ postup učení - rozlišuje, jak rozsáhlou informaci je žák schopen zpracovat najednou.

Výše uvedené charakteristiky žáka jsou vstupními jazykovými proměnnými jazykového modelu expertního systému ES1, který určuje styl učení žáka (Tab. č. 1). Aktuální číselné hodnoty všech čtyř vstupních proměnných modelu jsou získány vyhodnocením dotazníku k určení učebního stylu (Novotný, 2010). Dotazník sestavil S. Novotný, psycholog Ostravské univerzity, který při jeho tvorbě vycházel z prací (Felder a Soloman, 2004), (Sternberg a Grigorenko, 1999) a (Mareš a Skalská, 1994). Dotazník obsahuje 20 otázek s hodnotící škálou vyjadřující míru souhlasu či nesouhlasu s daným výrokem. Jednotlivé odpovědi jsou ohodnoceny body od 0 do 3 . Každá ze sledovaných vlastností je testována na pěti otázkách, proto žák může za své odpovědi získat hodnocení v rozmezí 0 až 15 bodů (Tab. č. 1).

\begin{tabular}{|c|c|c|c|c|}
\hline Jazyková proměnná & Id & Rozsah univerza & Jazykové hodnoty & Id \\
\hline \multirow{2}{*}{ SMYSLOVÉ VNÍMÁNÍ } & \multirow{2}{*}{ SV } & \multirow{2}{*}[0,15]{} & GRAFICKÉ & GRA \\
\hline & & & VERBÁLNÍ & VER \\
\hline \multirow{2}{*}{ POSTUP UČENÍ } & \multirow{2}{*}{$\mathrm{PU}$} & \multirow{2}{*}[0,15]{} & GLOBÁLNÍ & GLO \\
\hline & & & SEKVENČNÍ & SEK \\
\hline \multirow{2}{*}{$\begin{array}{l}\text { ZPU゚SOB ZPRACOVÁNÍ } \\
\text { INFORMACE }\end{array}$} & \multirow{2}{*}{$\mathrm{ZZI}$} & \multirow{2}{*}[0,15]{} & TEORETIK & TEO \\
\hline & & & PRAKTIK & PRA \\
\hline \multirow{2}{*}{ SOCIÁLNÍ ASPEKT } & \multirow{2}{*}{$\mathrm{SA}$} & \multirow{2}{*}[0,15]{} & INTROVERT & INT \\
\hline & & & EXTROVERT & EXT \\
\hline
\end{tabular}

Tab. č. 1: Vstupni jazykové proměnné ES1.

Učební styl žáka popisuje jazykový model ES1 pomocí 4 dimenzí (Felder a Silverman, 1998).

Smyslové vnímání vychází z názoru, že žák získává informace vizualizací (obrázky, symboly, diagramy) nebo sluchově (pomocí zvuků a slov). ES1 rozlišuje dva typy žáků:

- Vizuální typ, který si pamatuje nejlépe to, co vidí - např. obrázky, diagramy, grafy, časové osy, videa apod. Žák př̀i učení využívá především zrak, opírá se o vizuální představivost. Verbální informace mu však činí potíže, často je rychle zapomíná.

- Slovní typ, který si pamatuje hodně z toho, co slyší, a ještě více z toho, co slyší a následně sám interpretuje. Žákům tohoto typu vyhovují diskuze, ze kterých se mnoho naučí. Dávají přednost ústnímu vysvětlování před vizuální demonstrací. Učí se efektivně tím, že vysvětlují něco ostatním nebo někoho poslouchají (Felder a Silverman, 1998).

Dle postupu učení model systému ES1 rozlišuje typ: 
- Holista - ten má tendenci vnímat situaci v celku, globálně. Zaměřuje se na velké části obecných informací, od kterých se postupně propracovává $\mathrm{k}$ detailům. Analýza detailů mu činí potíže.

- Detailista - typ, který se zaměřuje na malé části konkrétních informací, ze kterých postupně skládá obraz celku. Má problém porozumět situaci v globálním rozměru (Riding a Cheema, 1991).

Dle způsobu zpracování informace a sociálního aspektu expertní systém rozlišuje čtyři typy žáků. : aktivní typ, reflexivní typ, aktivně-reflexivní typ a reflexivně-aktivní typ. Vychází ze skutečnosti, že komplexní psychické procesy, které přeměňují vnímanou informaci na znalost, se skládají ze dvou kategorií - aktivního experimentování a reflexivního pozorování (Felder a Silverman, 1998). Tyto kategorie doplňuje o zapojení do okolního sociálního prostředí, které žák při učení preferuje. Definuje tedy:

- Aktivní typ, který se mnoho nenaučí z frontální výuky, protože předává informace pasivně. Lépe se učí v situacích, které umožňují skupinovou práci a aktivní experimentování.

- Reflexivní typ - ten vyžaduje situace, které mu poskytnou příležitost přemýšlet o prezentované informaci. Je to spíše teoretik a raději pracuje sám nebo př́ípadně s jednou další osobou.

- Aktivně-reflexivní typ je teoretik, který upřednostňuje skupinovou práci (extrovert).

- Reflexivně-aktivní typ je praktik (experimentátor), který raději pracuje sám (introvert).

Uvedený přístup k rozhodnutí o typu žáka je formalizován v jazykovém modelu ESI třemi výstupními jazykovými proměnnými s jazykovými hodnotami, popsanými v Tab. č. 2.

\begin{tabular}{|c|c|l|l|}
\hline \multirow{2}{*}{ Jazyková proměnná } & \multirow{2}{*}{ Id } & \multicolumn{1}{|c|}{ Jazykové hodnoty } & \multicolumn{1}{|c|}{ Id } \\
\hline \multirow{3}{*}{$\begin{array}{c}\text { TYP REFLEXIVNÍ } \\
\text { nebo AKTIVNII }\end{array}$} & \multirow{2}{*}{ REF/AKT } & REFLEXIVNÍ & REF \\
\cline { 3 - 4 } & & REFLEXIVNĚ-AKTIVNÍ & RA \\
\cline { 3 - 4 } & & AKTIVNĚ- REFLEXIVNÍ & AR \\
\cline { 3 - 4 } & & AKTIVNÍ & AKT \\
\hline $\begin{array}{c}\text { TYP VIZUÁLNÍ } \\
\text { nebo VERBALNÍ }\end{array}$ & \multirow{2}{*}{ VIZ/SLO } & VIZUÁLNÍ & VIZ \\
\cline { 3 - 4 } $\begin{array}{c}\text { TYP HOLISTA } \\
\text { nebo DETAILISTA }\end{array}$ & \multirow{2}{*}{ HOL/DET } & SLOVNÍ & HOLO \\
\cline { 3 - 4 } & HETAILISTA & DEL \\
\hline
\end{tabular}

Tab. č. 2: Výstupní jazykové proměnné ES1.

Báze znalostí ES1 je tvořena soustavou podmíněných IF-THEN pravidel (1), jejichž podmínkové části představují všechny kombinace jazykových hodnot vstupních proměnných. Jednotlivé kombinace byly expertně (zkušeným pedagogem) ohodnoceny přiřazením příslušných jazykových hodnot výstupních proměnných. Např. pravidlo $R_{1}$ má tvar 
$R_{1}$ : IF (SA is INT) and (ZZI is TEO) and ( $\mathrm{SV}$ is GRA) and (PU is GLO) THEN (REF/AKT is REF) and (VIZ/SLO is VIZ) and (HOL/DET is HOL)

a formalizuje tuto znalost:

Jestliže se žák raději učí individuálně, teoreticky, lépe si pamatuje to, co vidí, a při učení upřednostñuje velké shluky informací, pak se jedná o žáka reflexivního, vizuálního a holistu.

Expertní systém ES1 je implementován ve vývojovém prostředí LFLC (Linguistic Fuzzy Logic Controller) - (Dvořák, Habiballa, Novák, a Pavliska, 2003). Aproximativní vyvození výstupních jazykových hodnot modelu je provedeno metodou Mamdani (Pokorný, 2012). Výstupem systému ES1 jsou všechny typy žáků, ohodnocené mírou (stupněm) jistoty, což je číslo z intervalu $<0,1>$. Čím je stupeň jistoty větší, tím více systém ztotožňuje žáka s daným typem. Obr. č. 2 ukazuje grafický výstup ES1 a představuje studenta spíše reflexivního, spíše verbálního a holistu. ES1 poskytuje žákovi komplexnější informaci o jeho učebním stylu, protože ukazuje míru shody jeho vlastností i s dalšími sledovanými typy žáků.

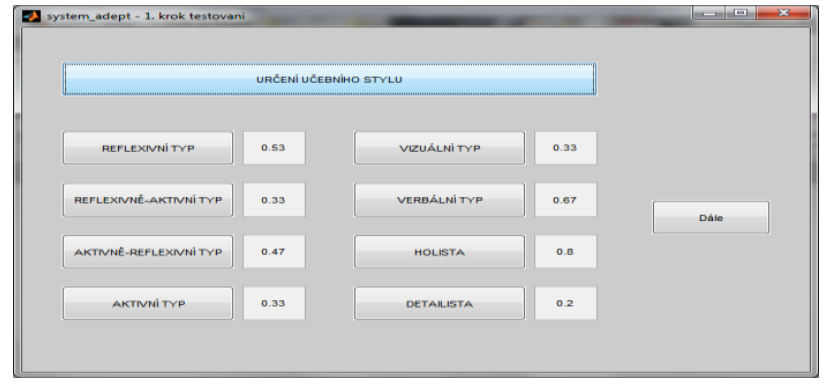

Obr. č. 2: Grafická podoba vyhodnocení učebniho stylu žáka - ohodnocené výstupní hodnoty systému ESI.

\section{Ověření funkčnosti jazykového modelu}

Po vytvoření jazykového fuzzy modelu expertního systému ES1 jsme začali testovat jeho kvalitu ve výuce. Série pedagogických experimentů proběhla na Moravské vysoké škole Olomouc v období leden 2016 - červen 2018. Experimentů se zúčastnilo 265 žáků 1. ročníku prezenčního studia. Žáci byli informování o průběhu celého pedagogického experimentu a následně vyplnili dotazník k určení jejich učebního stylu. Dotazník byl vyhodnocen systémem ESI, který určil styl učení každého žáka. Žák obdržel informace o svém způsobu učení a následně se $\mathrm{v}$ strukturovaném rozhovoru vyjádřil $\mathrm{k}$ tomu, zda získané výsledky odpovídají jeho učebnímu stylu. $98 \%$ respondentů uvedlo, že s výsledky expertního systému $E S I$ souhlasí, pouze $2 \%$ uvedla, že jejich styl učení je odlišný. Výsledky pedagogického experimentu jsou uvedeny v tabulce č. 3 . 


\begin{tabular}{|l|c|c|}
\hline \multicolumn{1}{|c|}{ Typ žáka } & Počet respondentů & Relativní četnost \\
\hline Spíše vizuální & 182 & 0,69 \\
\hline Spíše slovní & 83 & 0,31 \\
\hline Spíše aktivní & 173 & 0,65 \\
\hline Spíše reflexivní & 13 & 0,05 \\
\hline Spíše aktivně-reflexivní & 19 & 0,07 \\
\hline Spíše reflexivně-aktivní & 60 & 0,23 \\
\hline Spíše holista & 167 & 0,63 \\
\hline Spíšse detailista & 98 & 0,37 \\
\hline
\end{tabular}

Tab. č. 3: Výsledky pedagogického experimentu.

Z tab. č. 3 vyplývá, že ve sledované skupině převažují žáci vizuální (69 \%), aktivní $(65 \%)$ a holisté $(63 \%)$.

Soubor byl následně rozdělen dle pohlaví (108 mužů a 157 žen) a podroben analýze, zda je statisticky významný rozdíl $\mathrm{v}$ typech žáka mezi muži a ženami. Výsledky výzkumu uvádí Tab. č. 4. U obou pohlaví opět převažoval typ vizuální, aktivní a holista. U mužů však bylo zaznamenáno více holistů (78 \%) než u žen (55 \%).

\begin{tabular}{|l|r|r|c|c|}
\hline \multirow{2}{*}{\multicolumn{1}{c|}{ Typ žáka }} & \multicolumn{2}{c|}{ Počet respondentů } & \multicolumn{2}{c|}{ Relativní četnost } \\
\cline { 2 - 5 } & muži & ženy & muži & ženy \\
\hline Spíše vizuální & 74 & 104 & 0,69 & 0,66 \\
\hline Spíše slovní & 34 & 53 & 0,31 & 0,34 \\
\hline Spíše aktivní & 70 & 111 & 0,65 & 0,71 \\
\hline Spíše reflexivní & 5 & 5 & 0,05 & 0,03 \\
\hline Spíše aktivně-reflexivní & 9 & 10 & 0,08 & 0,06 \\
\hline Spíše reflexivně-aktivní & 24 & 31 & 0,22 & 0,20 \\
\hline Spíše holista & 84 & 87 & 0,78 & 0,55 \\
\hline Spíše detailista & 24 & 70 & 0,22 & 0,45 \\
\hline
\end{tabular}

Tab. č. 4: Výsledky pedagogického experimentu dle pohlaví.

\section{Diskuse}

Expertní systémy dokáží pracovat s neurčitými (vágními) informacemi. Závěry vyvozené těmito systémy jsou ohodnoceny stupněm jistoty, udávajícím, do jaké míry je závěr relevantní či nikoliv. V publikaci popsaný systém ES1 určuje učební styl žáka a navíc mu poskytuje komplexnější informaci o jeho způsobu učení, protože ukazuje míru shody jeho vlastností i s dalšími sledovanými typy žáků (jejich učebními styly). Tato komplexní informace je pro žáka důležitá, protože i když preferuje určitý styl učení a je v něm dobrý, ostatní styly také má, byt' třeba málo rozvinuté (Mareš, 2013). Učební styl se během života člověka mění jednak bezděčně (vyvíjí se), ale také záměrně - na základě vněǰš́ho řízení i autoregulace (Průcha, Walterová a Mareš, 2013), proto je znalost stylu učení pro každého jedince velmi důležitá. 
V současné době uvažujeme o dalším rozvoji systému ES1. Zvažujeme doplnění dalších učebních charakteristik žáků jako vstupních jazykových proměnných ES1. Jednalo by se konkrétně o doplnění vlastností autoregulace učení a motivace ke studiu. Tyto úpravy jazykového modelu systému ESI by dle našeho názoru zpřesnily určení stylu učení žáka.

Testováním systému ES1 ve výuce jsme získali cenné informace o učebním stylu současné populace. Jsme si vědomi, že vzorek respondentů není dostatečně reprezentativní, snažili jsme se však i v této situaci dosáhnout maximální korektnosti dosažených závěrů a zamyslet se nad tím, jak lze dosažené výsledky využít v pedagogické praxi. $Z$ výsledků pedagogických experimentů vyplývá, že většina žáků upřednostňuje při učení kreativní a aktivizující výukové metody. Proto je nutné žákům ve výuce nabídnout různé zábavné aktivity, zaměřené na praxi. Je vhodné zařadit metody heuristické, metody situační a inscenační, osvědčují se i didaktické hry (Průcha, ed. 2009). Pro většinu populace je totiž zážitkové vzdělávání nejefektivnější formou učení. Poznatky získané prožitím učební situace si obvykle pamatujeme déle a lépe než poznatky získané pasivním nasloucháním při frontální výuce.

Experiment také prokázal, že většina žáků upřednostňuje učivo, prezentované v obrazové podobě, např. v podobě obrázků, schémat, diagramů, grafů, map, fotografií, videa nebo filmu. Výbornou pomůckou jsou také myšlenkové mapy.

Učební styl vzniká na vrozeném základě (Průcha, Walterová, Mareš, 2009), proto je nutné pestré formy výuky nabízet žákům na všech typech škol. Dnešní učitelé by měli podporovat žáky v kombinaci učebních stylů a ve flexibilitě jejich používání. Poznání vlastního stylu učení již před začátkem učení je pro žáka užitečné a umožňuje cílené a individualizované zásahy do průběhu jeho učení s cílem zefektivnit tento proces.

$\mathrm{V}$ současné době se školy $\mathrm{v}$ ČR mohou zapojit do různých projektů, které jim umožňují postupně měnit tradiční formy výuky. Jedná se především o postupné zavádění inovativních př́stupů ve výuce, digitalizaci výukového procesu, zavádění interdisciplinárního a aplikačního pojetí výuky, která je více zaměřena na praktické dovednosti a propojování školy s praxí. Tyto cíle sleduje i projekt „Gramotnosti inovativně“, který je v současné době realizován na Střední škole - Podorlické vzdělávací centrum v Dobrušce (více informací na https://www.sspvc.cz/projekty/gramotnostiinovativne).

Dnešní př́istup ke vzdělávání preferuje učit žáky dovednostem, přivádět je k vlastním postojům. Modernizace vzdělávacího procesu $\mathrm{v}$ rámci inovace a zkvalitnění výuky by mělo být cílem všech současných škol.

\section{Poděkování}

Tento př́spěvek vznikl s finanční podporou a v rámci řešení projektu ESF reg. číslo: CZ.02.3.61/0.0/0.0/16_012/0000608 „Gramotnosti inovativně“.

\section{Závěr}

Učební styl je způsob, jak člověk vstřebává a zpracovává nové informace, a jak si je pamatuje. Každý z nás má svůj jedinečný učební styl, který během výuky upřednostňuje. Protože se učíme celý život, dá se říct, že určitý učební styl preferujeme celoživotně.

Základem pro rozpoznání učebních stylů u žáků je, aby se učitelé detailně seznámili s vlastním stylem učení (se svými sklony, přednostmi i slabými stránkami, oblíbenými oblastmi), jakož i s tím, jak svůj styl učení přenášejí do třídy, kde vyučují. Schopnost 
citlivě rozpoznat u žáků různé styly učení a lépe rozumět sobě i svým kolegům je pro učitele velmi cenná. Díky ní je totiž lépe vybaven $\mathrm{k}$ tomu, aby dokázal učit všechny typy žáků, včetně těch, kteří zápasí v oblasti učení, emocí a chování. K diagnostice stylů učení žáků lze využít i v této publikaci popsaný fuzzy orientovaný expertní systém ESI. Učební styl každého žáka se během jeho života vyvíjí. Je proto nutné, aby pedagog při výuce usiloval o všestranný rozvoj žáků formou zajímavých a zábavných aktivit zaměřených na praktickou stránku. Pestré výukové metody a inovativní př́stupy jsou také důležitým prvkem motivace a základem pro zapojení žáků do aktivní a smysluplné práce.

\section{Literatura}

Coffield, F. \& al. (2004). Learning styles and pedagogy in post-16 learning. In A systematic and critical review. London: Learning and skills research centre.

Dunn, R. \& K. Dunn. (1979). Learning Styles/Teaching Styles: ShouldThey...CanThey... Be Matched? In: Educational Leadership. (digital edition). Association for Supervision and Curriculum Development. 4(36). pp. 238-244.

Dvořák, A., Habiballa, H., Novák, V. a V. Pavliska. (2003). The concept of LFLC 2000 its specificity, realization and power of applications. Computers in Industry. 51(3). pp. 269-280.

Felder, F. M. \& L. K. Silverman. (1998). Learning/Teaching styles in engineering education. In Journal of engineering education, 78(8) pp. 674-681.

Felder, R. M. \& B. A. soloman. (2004). Index of Learning Styles. [online]. [cit. 2013-06-25]. Dostupné z: http://www.ncsu.edu/felder-public/ILSpage.html

Gregorec, A. F. (1979). Learning/teaching styles: Their nature and effects. In Student learning styles: Diagnosing and prescribing programs. Reston, VA: National Association of Secondary School Principals. pp. 19-26.

Honey, P. \& A. Mumford. (2002). Using your learning styles. Maidenhead: Peter Honey Publications.

Kostolányová, K. Teorie adaptivního e-learningu. (2012). Ostravská univerzita: Ostrava. Mareš, J. (1998). Styly učení žáků a studentio. 1. vyd. Praha: Portál.

Mareš, J. (2013). Pedagogická psychologie. Praha: Portál.

Mareš, J. a H. Skalská. (1994). LSI - dotazník stylů učeni pro žaky základních a středních škol. Psychológia a patopsychológia dietata a, 29(3). s. 248-264.

Mikulecký, P., Hynek, J. a I. Lenharčík. (2002). Znalostní technologie II. Gaudeamus: Hradec Králové.

Novák, V. (1990). Fuzzy množiny a jejich aplikace. SNTL Praha.

Novák, V. (2000). Základy fuzzy modelování. Praha: BEN.

Novotný, J. S. (2010). Individualization of teaching through e-learning: Development of Students' Learning Profile Questionnaire. In: Theoretical and Practical Aspects of Distance Learning. Katowice, Polsko: Studio Noa. pp 105-116.

Pask, G. (1976). Styles and strategies of learning. In British Journal of Educational Psychology. 46. pp. 129-148

Pokorný, M. (2012). Expertní systémy. Ostrava: Ostravská univerzita v Ostravě, PřF.

Pokorný, M. (1996). Umélá inteligence v modelování a ř́zení. Praha: Ben.

Pokorný, M. a Z. Krišová. (2016). Znalostni systémy. Olomouc: MVŠO.

Popper, M. a J. Kelemen. (1989). Expertné systémy. Bratislava: Alfa.

Průcha. J. ed. (2009). Pedagogická encyklopedie. Praha: Portál. 
Průcha, J., Walterová, E. a J. Mareš. (2013). Pedagogický slovnik. 7. vyd. Praha: Portál. Riding, R. J. \& I. Cheema. (1991). Cognitive styles - an overview and integration. In Educational psychology. 11(3-4). pp 193-215.

Sternberg, R. J. \& E. L. Grigorenko. (1999). Perspectives on Thinking, Learning and Cognitive Styles: a capsule history of theory and research on styles. N.Y.:LEA.

Genetics and intelligence. In Journal of American Academy of Child and Adolescent Psychiatry. 38. pp. 486-488.

Vlčková, K. (2007). Strategie učení cizímu jazyku: výsledky výzkumu použiváni strategií a jejich efektivity na gymnáziích. Brno: Paido. 